UDC 614.7

DOI: 10.21668/health.risk/2020.3.08.eng

Research article

\title{
ASSESSING EFFICIENCY OF PRE-AMMONIZATION AIMED AT REDUCING CARCINOGENIC RISKS CAUSED BY TRIHALOMETHANES IN DRINKING WATER
}

\author{
L.A. Deryabkina ${ }^{1}$, B.I. Marchenko, ${ }^{1,2}$, N.K. Plugotarenko ${ }^{2}$, A.I. Yukhno ${ }^{2}$ \\ ${ }^{1}$ Center for Hygiene and Epidemiology in Rostov Region, Taganrog Office, 16a Bol'shoi Ave., Taganrog, 347930, \\ Russian Federation \\ ${ }^{2}$ Southern Federal University, 105/42 Bol'shaya Sadovaya Str., Rostov-on-Don, 344006, Russian Federation
}

In most Russian regions there is still a pressing issue related to providing population with high quality and safe drinking water. Up to now, chlorination has been the primary technique applied to disinfect drinking water as it is highly efficient, reliable, and relatively cheap. However, when chlorine is used to disinfect natural water that contains organic pollutants, it results in risks of by-products occurrence. These products are trihalomethanes, epigenetic carcinogenesis promoters that cause elevated carcinogenic risks under oral, inhalation, and subcutaneous exposure.

Our research goal was to hygienically assess efficiency of pre-ammonization applied in water treatment procedures in order to prevent occurrence of carcinogenic organic chlorine compounds during chlorination and to minimize carcinogenic risks. We determined trihalomethanes and residual chlorine contents in model samples of natural water taken from a surface water source after chlorination with different doses of chlorine. We examined 52 pair parallel samples that had undergone pre-ammonization with ammonia sulfate and control ones. Trihalomethanes concentrations were determined in model water samples with gas-liquid chromatography.

Basing on the results obtained via experiments on laboratory chlorination of river water, we determined quantitative characteristics and built regression models showing dependence between concentrations of organic chlorine compounds occurring due to chlorination (chloroform, dichlorobrommethane, dibromchloromethane) and chlorine doses and preammonization parameters. It was established that pre-ammonization was the most efficient in terms of preventing trihalomethanes occurrence under such disinfection modes when contents of residual active chlorine didn't exceed recommended levels $(0.8-1.2 \mathrm{mg} / \mathrm{L})$. Basic ways to minimize carcinogenic risks caused by trihalomethanes are systemic control over their contents in drinking water during social and hygienic monitoring procedures; preliminary ammonization of water taken from surface water sources; prevention of unjustified hyper-chlorination; preliminary deep purification of initial water; disinfection with ultrasound radiation instead of preliminary chlorination; etc.

Key words: drinking water, chlorination, trihalomethanes, chloroform, dichlorobrommethane, dibromchloromethane, malignant neoplasms, carcinogenic risk, health risk assessment, social and hygienic monitoring.

An issue related to providing population with high quality and safe drinking water remains vital in most Russian regions $[1,2]$. At present the most widely spread procedure for providing safety of water taken form centralized communal and drinking water supply systems is disinfection with chlorine or chlorinecontaining reagents. Chlorination has certain benefits as it is efficient, reliable, has apparent after effects due to residual chlorine occurrence in distribution water supply networks, and is relatively cheap [3-5]. At the same time, when it comes to chlorinating water taken from surface water sources that contains natural and anthropogenic organic compounds, chlorination may result in occurrence of such by-products as trihalomethanes including chloroform (trichloromethane), dichloro-

(C) Deryabkina L.A., Marchenko B.I., Plugotarenko N.K., Yukhno A.I., 2020

Lyudmila A. Deryabkina - Candidate of Medical Sciences, Chief Physician of the branch (e-mail: tagcgsen@pbox.ttn.ru; tel.: +7 (863) 464-29-62; ORCID: https://orcid.org/0000-0002-0790-0365).

Boris I. Marchenko - Doctor of Medical Sciences, Docent, Professor, Epidemiologist of the branch (e-mail: borismarch@gmail.com; tel.: +7 (863) 437-16-24; ORCID: http://orcid.org/0000-0001-6173-329X).

Nina K. Plugotarenko - Candidate of Technical Sciences, Docent, Head of the Department of technosphere safety and (e-mail: plugotarenko@mail.ru; tel.: +7 (863) 437-16-35; ORCID: http://orcid.org/0000-0003-0853-8510).

Aleksandra I. Yukhno - Postgraduate of the Institute of high technologies and piezotechnics (e-mail: a.bachmackaja@gmail.com; tel.: +7 (863) 243-48-11; ORCID: http://orcid.org/0000-0002-9871-9261). 
brommethane, dibromchloromethane, etc. Probability of trihalomethanes occurrence grows linearly in case there is an increase in periods of time during which water is kept in tanks and distribution networks; it also depends on water temperature, doses of chlorine-containing reagents applied at water treatment facilities, and residual chlorine contents [6-13]. Occurrence of chloroform and other trihalomethanes in drinking water results in elevated risks of both potential carcinogenic and non-carcinogenic risks as such substances have epigenetic properties of carcinogenesis promoters under combined oral, inhalation, and subcutaneous exposure. These risks become apparent via increase in pathologies occurring in the liver, kidneys, cardiac muscle, blood system, nervous system, and endocrine system [14-23]. All the above mentioned means it is necessary to implement such water treatment procedures that will prevent or minimize trihalomethanes occurrence in drinking water in centralized water supply systems; for example, water can be disinfected with ultrasound radiation, or preammonization with subsequent chlorination can be applied, etc. [24].

Our research goal was to hygienically assess efficiency of pre-ammonization applied to prevent trihalomethanes occurrence during chlorination of water taken from surface water source for centralized communal and drinking water supply.

Data and methods. Our experiment research involved determining trihalomethanes and residual chlorine contents in model samples of natural water from the main water source for centralized and drinking water supply system in Taganrog (The Don river) after chlorination with different chlorine doses performed in a laboratory taking into account chlorine absorption capacity of water. Overall, we examined 52 pair parallel samples, experimental ones that underwent pre-ammonization with ammonia sulfate used as a reagent, and reference ones, that didn't undergo preliminary pre-ammonization. Trihalomethanes concentrations in model water samples were performed according to the State Standard (GOST) R 51392-99 ${ }^{1}$. Results obtained via experiments were statistically processed both with conventional variations statistic procedures and non-linear regression models showing dependence between chloroform, dichlorobrommethane, and dibromchloromethane concentrations on total residual active chlorine contents. We applied our own software package that provided an opportunity to use procedures for statistical processing of experimental results and mathematical modeling including «Turbo Dynamics», version 1.02 (long-term dynamics analysis, extrapolation prediction) and «Turbo Correlation», version 1.1 (non-linear and multiple correlation and regression analysis); we also used IBM SPSS Statistics («Statistical Package for Social Science») version 19.0 an expert statistic software package.

Results and discussion. It is truly vital to reveal potential carcinogenic risk factors in Taganrog, a city in Rostov region, with its population being approximately 250 thousand people as an existing situation regarding morbidity with malignant neoplasms is extremely bad there. Average long-term morbidity with $\mathrm{MN}$ over the last 15 years is equal to $486.42 \%$ oooo which is 1.31 times higher than for urban population in Rostov region in general and it occupies the first rank place in the overall morbidity structure in the city. Average annual growth in longterm trend describing overall oncologic morbidity over the given period amounts to $+1.07 \%$, and priority localizations in its structure are skin (without melanoma, $14.81 \%$ ), breast $(13.08 \%)$, trachea, bronchial tubes,

\footnotetext{
${ }^{1}$ GOST R 51392-99. Drinking water. Determining contents of volatile halogen-organic substances with gas liquid chromatography. Approved upon and made valid by the Order of the RF Gosstandart on issued on December 15, 1999 г. N 515 -st. KODEKS: an electronic fund for legal and reference documentation. Available at: http://docs.cntd.ru/document/gost-r-51392-99 (03.08.2020) (in Russian).
} 
and lung (9.22\%), middle intestine (6.94\%), and stomach $(6.49 \%)$.

The centralized water supply system in Taganrog is a mixed one as it supplies water taken both from surface sources (the Don, the Mius) and underground ones (two territorially separate water intakes). River water goes to treatment facilities where it undergoes twostage treatment in horizontal tanks and fast filters with coagulation, pre-ammonization with ammonia sulfate, and double chlorination with chlorine water used as a reagent.

According to data obtained from the Center for Hygiene and Epidemiology in Rostov region, Taganrog office, hygienic assessment of drinking water quality revealed chloroform (trichloromethane), dichlorobrommethane, and dibromchloromethane in it; still, water quality can be considered relatively satisfactory. Thus, according to research results, 276 water samples were examined over 2012-2019, and chloroform contents higher than MPC were detected in a single one $(0.36 \%)$, and there were no samples with dichlorobrommethane or dibromchloromethane contents that exceeded MPC. Potential carcinogenic risk was assessed basing on well-grounded maximum exposure calculated as upper limits of $95 \%$ confidence intervals of average trihalomethanes concentrations [25]. It was detected that total individual carcinogenic risk caused by oral exposure to trihalomethanes in water from centralized water supply system (CRwo) was estimated as maximum permissible over the whole 8-year period and was equal to $6.91 \cdot 10^{-6}$ with priority share contribution into it made by dibromchloromethane (55.8\%). A contribution made by the said parameter by chloroform $\left(7.09 \cdot 10^{-7}\right)$ is negligible and corresponds to De minimis level. There was also maximum permissible level $\left(2.27 \cdot 10^{-6}\right)$ detected for the total carcinogenic risk caused by inhalation exposure to trihalomethanes in water from centralized water supply systems (CRwi) with the greatest share contribution belonging to dichlorobrommethane (54.3\%).
Individual carcinogenic risk caused by subcutaneous exposure to trihalomethanes (CRwd) turned out to be negligible $\left(6.11 \cdot 10^{-7}\right)$. Therefore, we detected the maximum permissible total individual multi-exposure carcinogenic risks (TCRw) caused by trihalomethanes in ater taken from centralized communal and drinking water supply systems in Taganrog as per data collected over 2012-2019. The total carcinogenic risk amounted to $9.79 \cdot 10^{-6}$ with share contributions made by oral, inhalation, and subcutaneous exposure being equal to $70.6 \%, 23.2 \%$, and $6.2 \%$ accordingly. Total lifelong population multi-exposure carcinogenic risk (TPCRw) that occurred due to oral, inhalation, and subcutaneous exposure to chloroform, dichlorobrommethane, and dibromchloromethane amounted to 2.477 as per data collected over the examined 8-year period. Analysis of long-term dynamics regarding total population multi-exposure carcinogenic risk varying from $5.91 \cdot 10^{-3}$ to $1.16 \cdot 10^{-1}$ has revealed there is a descending trend in it with annual average growth rate being equal to $-37.17 \%$. Therefore, the obtained results indicate that combined disinfection procedures applied at treatment faculties of the city centralized water supply system are highly efficient. These procedures involve both chlorination and pre-ammonization with ammonia sulfate that binds introduced chlorine; it results in chloramines occurrence that prevents trihalomethanes formation.

We continued experimental research on efficiency of preliminary ammonization applied in water treatment procedures and proceeded to quantitative modeling of dependence between trihalomethanes concentrations occurring in model water samples (chloroform, dichlorobrommethane, and dibromchloromethane) and parameters of preammonization with ammonia sulfate during chlorination performed in laboratory conditions (from 0.7 to $3.0 \mathrm{mg} / \mathrm{dm}^{3}$ ) taking into account chlorine absorption capacity of water and residual chlorine determination [26]. Simultaneously, we examined reference water 
samples that were chlorinated with the same chlorine doses but without any preliminary ammonization. After 30-minute exposure we applied gas liquid chromatography to determine trihalomethanes contents in model water samples and we also measured total residual active chlorine contents. Research results prove that, first of all, trihalomethanes concentrations grow non-linearly depending on introduced chlorine doses and, secondly, trihalomethanes contents in reference water samples is substantially higher that the same parameters of water samples that have been through preliminary ammonization. Preammonization was the most efficient under chlorination modes that provided total residual active chlorine contents remaining within hygienic standards $\left(0.8-1.2 \mathrm{mg} / \mathrm{dm}^{3}\right)$. Thus, when total residual active chlorine contents in experimental water samples were equal to $1.2 \mathrm{mg} / \mathrm{L}$, chloroform concentration was 7.29 times lower in them than in reference samples, and pre-ammonization efficiency turned out to be even higher for dichlorobrommethane and dibromchloromethane, 16.33 and 59.01 times accordingly.

Basing on the obtained experimental data, we revealed strong direct statistically significant correlations between trihalomethanes concentrations detected in model water samples and total residual active chlorine contents; these correlations are most adequately described with non-linear regression models built up as exponential curves for experimental samples that were pre-ammonized and logarithmic curves for reference samples that were not (Table 1).

Developed non-linear regression models clearly show a negative effect, that is, preammonization efficiency regarding prevention of trihalomethanes occurrence is going down progressively when total residual active chlorine contents exceeds the hygienic standard $\left(0.8-1.2 \mathrm{mg} / \mathrm{dm}^{3}\right)$; in particular, such a situation can occur when water is disinfected via hyper-chlorination procedure (Figures 1-3).

Table 1

Non-linear regression models showing dependence between trihalomethanes concentrations and total residual active chlorine contents after laboratory disinfections of river water samples

\begin{tabular}{|c|c|c|c|c|c|}
\hline \multirow[b]{2}{*}{ Trihalomethane } & \multirow[b]{2}{*}{$\begin{array}{c}\text { Laboratory } \\
\text { conditions for a } \\
\text { model solution } \\
\text { chlorination }\end{array}$} & \multicolumn{4}{|c|}{ Non-linear regression models } \\
\hline & & \begin{tabular}{|c|} 
Correlation \\
coefficient \\
$(\mathrm{rYX})$
\end{tabular} & $\mid \begin{array}{c}\text { Statistic sig- } \\
\text { nificance } \\
\text { (p-level) }\end{array}$ & $\begin{array}{l}\text { Regression } \\
\text { line type }\end{array}$ & $\begin{array}{l}\text { Non-linear models showing } \\
\text { dependence between triha- } \\
\text { lomethanes concentrations }(\mathrm{Y}) \\
\text { An total residual active chlo- } \\
\text { rine contents in water }(\mathrm{X})\end{array}$ \\
\hline \multirow{2}{*}{ Chloroform } & pre-ammonized & 0.838 & $p<0,01$ & $\begin{array}{l}\text { exponential } \\
\text { curve }\end{array}$ & $Y=0.000737 \cdot X^{3.822}$ \\
\hline & $\begin{array}{c}\text { without pre- } \\
\text { ammonization }\end{array}$ & 0.745 & $p<0,05$ & $\begin{array}{l}\text { logarithmic } \\
\text { curve }\end{array}$ & $\mathrm{Y}=0.023445+0.019443 \cdot \log (\mathrm{X})$ \\
\hline \multirow{2}{*}{$\begin{array}{c}\text { Dibrom- } \\
\text { chloromethane }\end{array}$} & pre-ammonized & 0.808 & $p<0,01$ & $\begin{array}{l}\text { exponential } \\
\text { curve }\end{array}$ & $Y=0.000024 \cdot X^{7.102467}$ \\
\hline & $\begin{array}{c}\text { without pre- } \\
\text { ammonization }\end{array}$ & 0.817 & $p<0,01$ & $\begin{array}{l}\text { logarithmic } \\
\text { curve }\end{array}$ & $\mathrm{Y}=0.033443+0.051431 \cdot \log (\mathrm{X})$ \\
\hline \multirow{2}{*}{$\begin{array}{c}\text { Dichloro- } \\
\text { brommethane }\end{array}$} & pre-ammonized & 0.739 & $p<0,05$ & $\begin{array}{l}\text { exponential } \\
\text { curve }\end{array}$ & $Y=0.000551 \cdot X^{3.849085}$ \\
\hline & $\begin{array}{c}\text { without pre- } \\
\text { ammonization }\end{array}$ & 0.851 & $p<0,01$ & $\begin{array}{l}\text { logarithmic } \\
\text { curve }\end{array}$ & $\mathrm{Y}=0.024353+0.027236 \cdot \log (\mathrm{X})$ \\
\hline
\end{tabular}




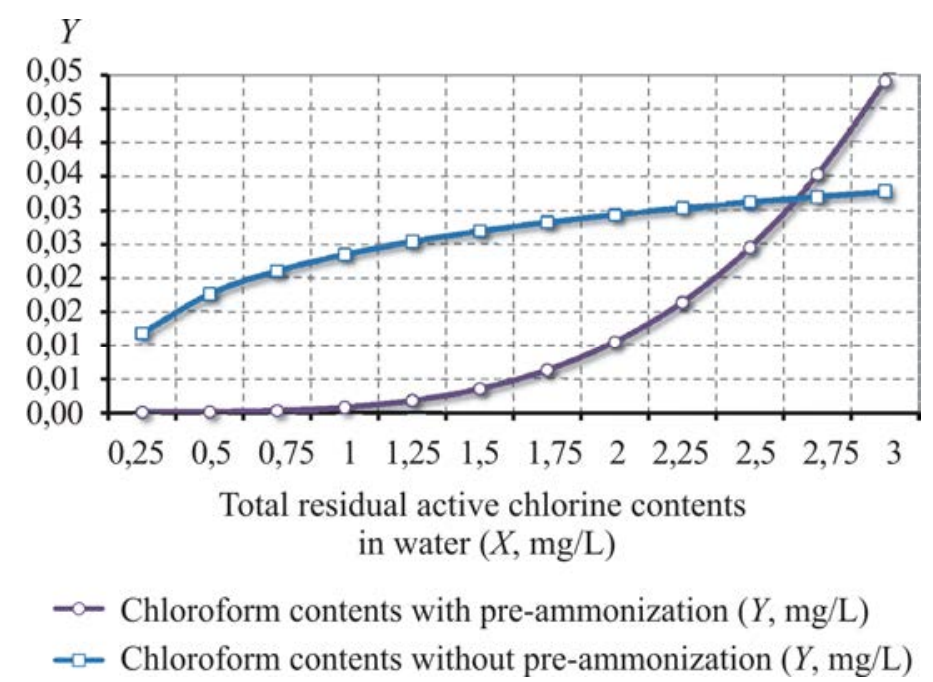

Figure 1. Non-linear regression models showing dependence between chloroform concentration and total residual active chlorine contents in model river water samples

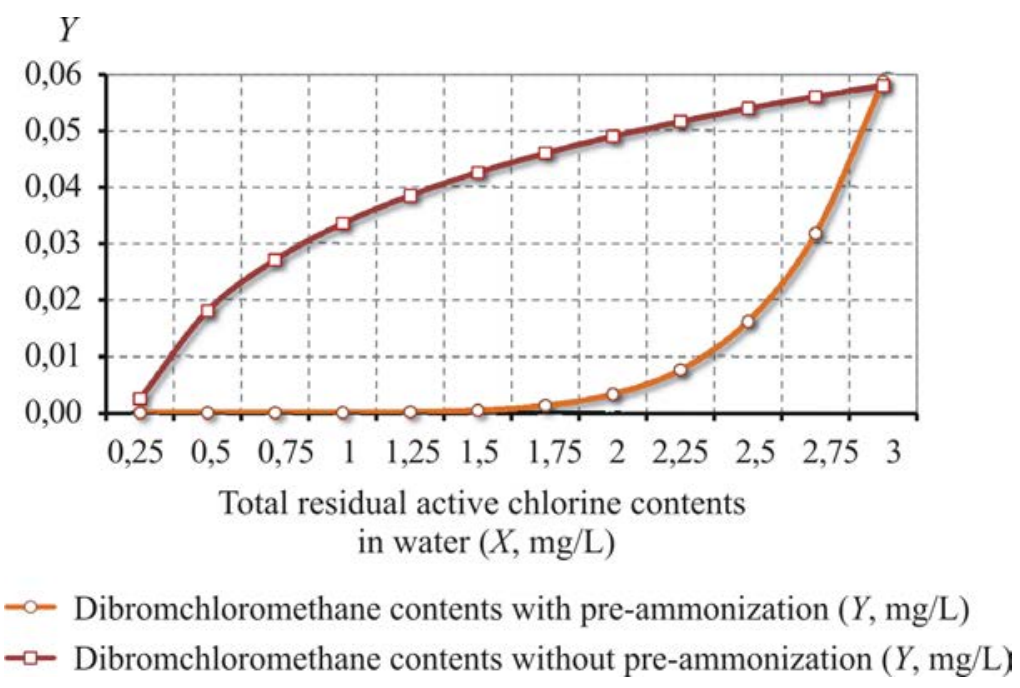

Figure 2. Non-linear regression models showing dependence between dibromchloromethane concentration and total residual active chlorine contents in model river water samples

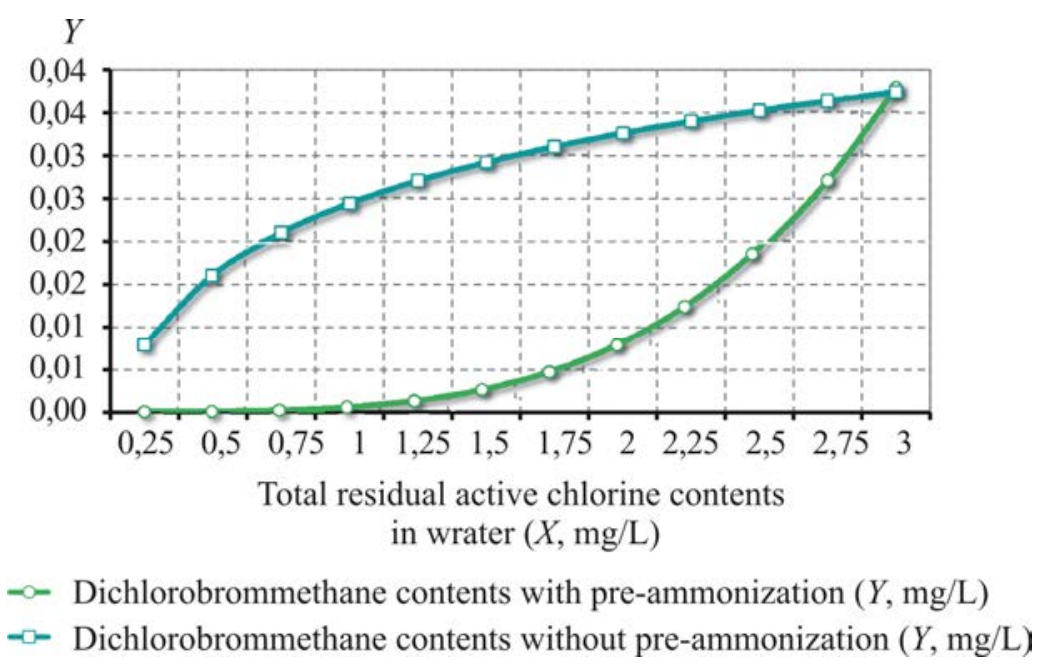

Figure 3. Non-linear regression models showing dependence between dichlorobrommethane concentration and total residual active chlorine contents in model river water samples 
Therefore, experimental research results allow us to conclude that the most efficient pre-ammonization aimed at preventing or minimizing occurrence of the examined trihalomethanes (chloroform, dichlorobrommethane, and dibromchloromethane) during water treatment requires such chlorination procedures that do not result in total residual active chlorine contents being higher than hygienic standards. Pre-ammonization is efficient due to chlorine being bound as a result of chloramines occurrence; the procedure leads to a substantial decrease in redox potential of «natural water - chlorine» system and chlorine absorption capacity of water since chloramines possess much more humble oxidizing potential than free chlorine. An apparent decrease in pre-ammonization efficiency in situations when too high chlorine doses are applied can be related to a double effect that occurs in case chlorine absorption capacity of water is rather low. First of all, excessive active chlorine that remains in water after hyper-chlorination results in much more intense oxidation and destruction of monochloramine that occurred in it due to pre-ammonization; consequently, additional free active chlorine contents occur in water.
Secondly, excessive free active chlorine interacts with organic compounds that can be found in natural water and it leads to increased trihalomethanes contents in it.

There are certain promising measures that can help decrease potential carcinogenic risks caused by trihalomethanes. Apart from systematic control over their contents in drinking water, including activities performed within social and hygienic monitoring, preliminary ammonization in water treatment, and maximum precise chlorine dosing in disinfection of water taken from natural sources, we can suggest considering, first of all, deep natural water purification prior to chlorination in order to minimize organic compounds contents in it as they are predecessor to trihalomethanes; secondly, we suggest applying post-chlorination at final stages in water treatment together with primary chlorination exclusion; and thirdly, we advise transition to reagentless disinfection of water in centralized water supply systems, for example, ultrasound radiation.

Funding. The research was not granted any sponsor support.

Conflict of interests. The authors declare there is no any conflict of interests.

\section{References}

1. Rakhmanin Yu.A., Mikhaylova R.I., Kiryanova L.F., Sevostyanova Ye.M., Ryzhova I.N, Skovronsky A.Yu. Important problems of high quality drinking water supply, and the ways of their solution. Vestnik RAMN, 2006, no. 4, pp. 9-17 (in Russian).

2. Tulakin A.V., Tsyplakova G.V., Ampleeva G.P., Kozyreva O.N., Pivneva O.S., Trukhina G.M. Regional problems of the provision of hygienic reliability of drinking water consumption. Gigiena i sanitariya, 2016, vol. 95, no. 11, pp. 1025-1028 (in Russian).

3. Sokolova N.F. Sredstva i sposoby obezzarazhivaniya vody (analiticheskii obzor) [Ways and means for water disinfection (analytical review)]. Meditsinskii alfavit, 2013, vol. 1, no. 5, pp. 44-54 (in Russian).

4. Mullina E.R. Chemical aspects of the process of water chlorination. Mezhdunarodnyi zhurnal prikladnykh i fundamental'nykh issledovanii, 2016, vol. 4, no. 12, pp. 609-613 (in Russian).

5. Miftakhova K.R., P'yankova O.G., Rudakova L.V., Glushankova I.S. Chlorination is the main method of disinfection of drinking water. Ekologiya i nauchno-tekhnicheskii progress. Urbanistika, 2015, vol. 1, pp. 233-242 (in Russian).

6. Slavinskaya G.V. Chlorination effect on quality of drinking water. Khimiya i tekhnologiya vody, 1991, vol. 13, no. 11, pp. 28-43 (in Russian). 
7. Lutsevich I.N. Hygienic estimation of transformation of complex organic substances resulting from decontamination of water by chlorine. Kazanskii meditsinskii zhurnal, 2003, vol. 84, no. 2, pp. 142-145 (in Russian).

8. Kantor L.I., Kharabrin S.V. some regularities of trihalogenomethanes formation during the water disinfection. Vodosnabzhenie i sanitarnaya tekhnika, 2004, no. 4-2, pp. 45-47 (in Russian).

9. Wong H., Mok K.M., Fan X.J. Natural organic matter and formation of trihalomethanes in two water treatment processes. Desalination, 2007, vol. 210, no. 1-3, pp. 44-51. DOI: 10.1016/j.desal.2006.05.031

10. Richardson S.D. Disinfection by-products and other emerging contaminants in drinking water. Trends in Analytical Chemistry, 2003, vol. 22, no. 10, pp. 666-684. DOI: 10.1016/S01659936(03)01003-3

11. Reckhow D.A., Singer P.C. Clorination By-products in Drinking Waters: From Formation Potentials to Finished Water Concentrations. Journal AWWA, 1990, no. 4, pp. 173-180. DOI: 10.1002/j.1551-8833.1990.tb06949.x

12. Valdivia-Garcia M., Weir P., Frogbrook Z., Graham D., Werner D. Climatic, Geographic and Operational Determinants of Trihalomethanes (THMs) in Drinking Water Systems. Aqua, 2016, vol. 6, pp. 318-323. DOI: $10.1038 /$ srep35027

13. Nokes C.J., Fenton E., Randall C.J. Modeling the formation of brominated trihalomethanes in chlorinated drinking waters. Water research, 1999, vol. 33, no. 17, pp. 3557-3568. DOI: $10.1016 / \mathrm{S} 0043-1354(99) 00081-0$

14. Zaitseva N.V., May I.V., Kleyn S.V., Sedusova E.V. An experience of establishing and proving of harm to the public health caused by consumption of drinking water containing hyperchlorination products. Zdorov'e naseleniya i sreda obitaniya, 2015, no. 12, pp. 16-18 (in Russian).

15. Egorova N.A., Bukshuk A.A., Krasovskii G.N. Hygienic assessment of drinking water chlorination by-products in view of multiroute exposure. Gigiena i sanitariya, 2013, vol. 92, no. 2, pp. 18-24 (in Russian).

16. Zhuravlev P.V., Aleshnya V.V., Shelyakina T.V., Golovina S.V. Vliyanie uslovii vodopol'zovaniya na onkozabolevaemost' naseleniya [Influence exerted by conditions of water use on oncologic morbidity among population]. Gigiena i sanitariya, 2000, no. 6, pp. 28-30 (in Russian).

17. Krasovskii G.N., Egorova N.A. Chlorination of water as a high hazard to human health. Gigiena i sanitariya, 2003, no. 1, pp. 17-21 (in Russian).

18. Ushakova T.I., Revich B.A., Aksel' E.M., Levshin V.F. Stoikie khlororganicheskie soedineniya kak faktor riska razvitiya raka molochnoi zhelezy [Resistant organic chlorine compounds as carcinogenic risk factor causing breast cancer]. Voprosy onkologii, 2002, vol. 48, no. 3, pp. 293-300 (in Russian).

19. Chernichenko I.A., Serdyuk A.M., Litovchenko O.N., Balenko N.V. Carcinogenic hazard of chloroform and other drinking water chlorination by-products. Gigiena i sanitariya, 2009, no. 3, pp. 28-32 (in Russian).

20. Malkova M.A., Zhigalova A.V., Khuziakhmetova A.A. Egorova, N.N., Vozhdaeva M.Yu., Kantor E.A. Comparison of the quality of drinking water with the incidence of the population on the content of trihalomethanes. Sovremennye problemy nauki i obrazovaniya, 2017, no. 3, pp. 145-146 (in Russian).

21. Hrudey S.E. Chlorination disinfection by-products, public health risk tradeoffs and me. Water research, 2009, vol. 43, pp. 2057-2092.

22. Hood E. Tap Water and Trihalomethanes: Flow of Concerns Continues. Environ Health Perspect, 2005, vol. 113, no. 7, pp. A474.

23. Cantor K.P. Carcinogens in drinking water: the epidemiologic evidence. Reviews on Environmental Health, 2010, vol. 25, no. 1, pp. 9-16. DOI: 10.1515/reveh.2010.25.1.9

24. Kalashnikova E.G., Arutyunova I.Yu., Gorina E.N., Kalashnikova O.B., Malyshev B.V. Redaction in the content of organochlorine compounds in potable water. Vodosnabzhenie i sanitarnaya tekhnika, 2005, no. 10-1, pp. 11-17 (in Russian). 
25. Onishchenko G.G., Novikov S.M., Rakhmanin Yu.A., Avaliani S.L., Bushtueva K.A. Osnovy otsenki riska dlya zdorov'ya naseleniya pri vozdeistvii khimicheskikh veshchestv, zagryaznyayushchikh okruzhayushchuyu sredu [Basics of health risk assessment under exposure to chemicals that pollute the environment]. Moscow, NII ECh i GOS Publ., 2002, 408 p. (in Russian).

26. Yuhno A.I., Plugotarenko N.K. Analysis of the formation of organochlorine compounds in drinking water. Tekhnologii tekhnosfernoi bezopasnosti, 2018, vol. 3, no. 79, pp. 28-35 (in Russian).

Deryabkina L.A., Marchenko B.I., Plugotarenko N.K., Yukhno A.I. Assessing efficiency of preammonization aimed at reducing carcinogenic risks caused by trihalomethanes in drinking water. Health Risk Analysis, 2020, no. 3, pp. 69-76. DOI: 10.21668/health.risk/2020.3.08.eng

Received: 09.06.2020

Accepted: 18.08.2020

Published: 30.09 .2020 